1-6-2009

\title{
Surface Cracks Record Long-Term Seismic Segmentation of the Andean Margin
}

John P. Loveless

Cornell University, jloveles@smith.edu

Richard W. Allmendinger

Cornell University

Matthew E. Pritchard

Cornell University

Jordan L. Garroway

Cornell University

Gabriel González

Universidad Católica del Norte

Follow this and additional works at: https://scholarworks.smith.edu/geo_facpubs

Part of the Geology Commons

\section{Recommended Citation}

Loveless, John P.; Allmendinger, Richard W.; Pritchard, Matthew E.; Garroway, Jordan L.; and González, Gabriel, "Surface Cracks Record Long-Term Seismic Segmentation of the Andean Margin" (2009). Geosciences: Faculty Publications, Smith College, Northampton, MA.

https://scholarworks.smith.edu/geo_facpubs/13

This Article has been accepted for inclusion in Geosciences: Faculty Publications by an authorized administrator of Smith ScholarWorks. For more information, please contact scholarworks@smith.edu 
Publisher: GSA

Journal: GEOL: Geology

Article ID: G25170

\section{Surface cracks record long-term seismic segmentation of}

2 the Andean margin

3 John P. Loveless ${ }^{1,2}$, Richard W. Allmendinger ${ }^{1}$, Matthew E. Pritchard ${ }^{1}$, Jordan L.

4 Garroway $^{1}$, Gabriel González ${ }^{3}$

$5{ }^{1}$ Department of Earth and Atmospheric Sciences, Cornell University, Snee Hall, Ithaca,

6 New York 14853, USA

$7 \quad{ }^{2}$ Current address: Department of Earth and Planetary Sciences, Harvard University, 20

8 Oxford Street, Cambridge, Massachusetts 02138, USA

$9{ }^{3}$ Departamento de Ciencias Geológicas, Universidad Católica del Norte, Casilla 1280,

10 Antofagasta, Chile

11 ABSTRACT

12 Understanding the long-term patterns of great earthquake rupture along a

13 subduction zone provides a framework for assessing modern seismic hazard. However,

14 evidence that can be used to infer the size and location of past earthquakes is typically

15 erased by erosion after a few thousand years. Meter-scale cracks that cut the surface of

16 coastal areas in northern Chile and southern Peru preserve a record of earthquakes

17 spanning several hundred thousand years owing to the hyperarid climate of the region.

18 These cracks have been observed to form during and/or shortly after strong subduction

19 earthquakes, are preserved for long time periods throughout the Atacama Desert,

20 demonstrate evidence for multiple episodes of reactivation, and show changes in

21 orientation over spatial scales similar to the size of earthquake segments. Our 
Publisher: GSA

Journal: GEOL: Geology

Article ID: G25170

22 observations and models show that crack orientations are consistent with dynamic and

23 static stress fields generated by recent earthquakes. While localized structural and

24 topographic processes influence some cracks, the strong preferred orientation over large

25 regions indicates that cracks are primarily formed by plate boundary-scale stresses,

26 namely repeated earthquakes. We invert the crack-based strain data for slip along the

27 well-known Iquique seismic gap segment of the margin and find consistency with gravity

28 anomaly-based inferences of long-term earthquake slip patterns, as well as the magnitude

29 and location of the November 2007 Tocopilla earthquake. We suggest that the meter-

30 scale cracks can be used to map characteristic earthquake rupture segments that persist

31 over many seismic cycles, which encourages future study of cracks and other small-scale

32 structures to better constrain the persistence of asperities in other arid, tectonically active

33 regions.

\section{INTRODUCTION}

35 The characteristic earthquake model of seismic recurrence suggests that a given

36 fault segment ruptures repeatedly in earthquakes of similar magnitude and areal extent

37 (Schwartz and Coppersmith, 1984). While some historical (Comte and Pardo, 1991) and

38 paleoseismic (Sieh, 1996) records support this model, it is unclear whether these seismic

39 segments are truly long-lived, because geologic indicators of distinct earthquakes usually

40 persist for only a few k.y. (up to $\sim 10$ events). To assess the longevity of the segmented

41 nature of seismicity, we require data that reflect deformation caused by 100 s to 1000 s of

42 repeated earthquakes. 
Publisher: GSA

Journal: GEOL: Geology

Article ID: G25170

Arrays of meter-scale surface cracks that penetrate coastal regions of the northern

44 Chile and southern Peru forearc provide insight into the long-term nature of great

45 earthquakes (magnitude 8 and larger) along the plate boundary. We use 2.5-m resolution

46 satellite imagery available in Google Earth to map concentrations of cracks throughout

47 the Andean forearc between $17.5^{\circ}$ and $23.5^{\circ} \mathrm{S}$ (Fig. 1); examination of regions outside

48 these latitudinal bounds yields only sparse examples of cracking, likely due to slightly

49 wetter climatic conditions (Ewing et al., 2006) and presence of unconsolidated sediment

50 (Rech et al., 2003), both of which inhibit crack preservation. We complement the remote

51 sensing with field observations at several localities (Loveless, 2008; Loveless et al.,

52 2005) and, because cracks throughout the study area are morphologically similar, we

53 generalize our field results to regions we have not visited. In general, crack clusters show

54 preferred orientations that vary on spatial scales similar to great earthquake rupture areas.

55 Between $19^{\circ}$ and $23^{\circ} \mathrm{S}$, which mark the estimated latitudinal bounds of the great 1877

56 Iquique earthquake (Comte and Pardo, 1991), mean length-weighted crack strike rotates

57 from NW to NNE. At several localities including east of the Mejillones Peninsula $\left(23^{\circ} \mathrm{S}\right)$,

58 there are populations of cracks showing a bimodal distribution in strike, with one set

59 striking NE and the other NW (Fig. 1). Cracks near Ilo, Peru strike at a high angle to the

60 coastline and plate boundary, approximately parallel to the direction of plate

61 convergence.

62 Hyperaridity in the region, which has persisted for at least the last 6 M.y. (Hartley

63 and Chong, 2002), if not since before 16-18 Ma (Dunai et al., 2005; Rech et al., 2006),

64 allows for long-term preservation of the cracks. The gypsum-indurated soil that covers 
Publisher: GSA

Journal: GEOL: Geology

Article ID: G25170

65 much of the coastal region between elevations of 300 and $1200 \mathrm{~m}$ (Rech et al., 2003)

66 provides a durable surface crust that further enhances crack preservation. Our field

67 observations reveal crack apertures ranging from $10 \mathrm{~s} \mathrm{of} \mathrm{cm}$ to more than $1 \mathrm{~m}$; these

68 cracks can be mapped using the imagery, but we cannot comprehensively define their

69 apertures. Although many cracks are preserved in the gypsum-indurated crust (Fig. 1,

70 inset), there are numerous fissures penetrating up to $12 \mathrm{~m}$ into bedrock. We interpret the

71 numerous layers of gypsum plated vertically onto crack walls as indication of repeated

72 episodes of sealing and reopening. The rate of gypsum accumulation is unknown,

73 limiting the information that it can provide about the age of cracks. However, based on

74 cosmogenic dating of the geomorphic surfaces into which the cracks cut and

75 morphologically similar neotectonic structures (González et al., 2006), we propose that

76 the cracks represent deformation as old as several hundred k.y., encompassing 1000s of

$77 \sim 100 \mathrm{yr}$ interplate earthquake cycles (Loveless et al., 2005).

78 Local structural, topographic, and/or geomorphic effects and stresses related to

79 earthquakes within the subducting slab (Marquardt et al., 2006) influence formation of

80 some cracks. In particular, some cracks strike parallel to crustal faults (González et al.,

81 2008) and drainages (Keefer and Moseley, 2004), indicating that pre-existing linear

82 features can affect crack strike. However, the large scale patterns of strike change (Fig.

83 1) and the fact that cracks were generated by the $1995 M_{w} 8.1$ Antofagasta, Chile

84 (González and Carrizo, 2003) and $2001 M_{w} 8.5$ Arequipa, Peru events (Keefer and

85 Moseley, 2004) indicate that interplate earthquakes are the principal driver of formation.

86 Mode 1 cracks - which, based on the paucity of observed lateral offset, we infer most 
Publisher: GSA

Journal: GEOL: Geology

Article ID: G25170

87 cracks to be (Loveless et al., 2005) - open in the direction of least compressional

88 principal stress $\left(\sigma_{3}\right)$ and therefore strike parallel to the most compressional direction $\left(\sigma_{1}\right)$

89 (Pollard and Segall, 1987). By constructing a regional map of crack strikes, we

90 effectively map the orientations of the principal stress axes responsible for their

91 formation. The stress field produced by a subduction zone earthquake varies as a function

92 of the slip distribution on the fault, with $\sigma_{1}$ axes varying from nearly parallel to the fault

93 slip vector around the center of the rupture zone to oblique to the slip direction near the

94 rupture terminations (Fig. 2).

\section{MODELING COSEISMIC STRESS FIELDS}

96 In order to explore the relationships between the mode 1 surface cracks and plate

97 boundary earthquakes, we calculate the coseismic principal deviatoric stress fields related

98 to great earthquakes on four segments of the Andean margin: the 2001 Arequipa, 1868

$99 M \sim 8.5$ southern Peru, $1877 M \sim 8.5$ Iquique, Chile, and 1995 Antofagasta events (rupture

100 areas shown in Figure 1; Detailed discussion appears in data repository ${ }^{1}$ ). We use

101 published solutions for slip distributions of the 1995 (Pritchard et al., 2006) and 2001

102 (Pritchard et al., 2007) events and approximations of the historical earthquake slip

103 patterns (Comte and Pardo, 1991). Figs. DR1-DR4 illustrate the relationships between the

104 forward models of coseismic static stress fields and the permanent strain demonstrated by

105 the surface cracks.

106 In general, there is good agreement between the observed mean strikes of cracks

107 and the orientation of modeled $\sigma_{1}$ axes. In the case of the bimodal strike crack

108 populations east of the Mejillones Peninsula, we find that the NW striking cracks are 
Publisher: GSA

Journal: GEOL: Geology

Article ID: G25170

109 consistent with the NE-SW directed $\sigma_{3}$ axes induced by events on the Antofagasta

110 segment (Fig. DR1), while the NE striking cracks are opened by the NW-SE trending $\sigma_{3}$

111 axes related to seismicity on the Iquique segment (Fig. DR2). Similarly, the bimodal

112 crack clusters in northernmost Chile are affected by stress related to earthquakes on the

113 Iquique and southern Peru segments of the margin (Figs. DR2, DR3).

114 The rotation of mean crack strike from NNE to NW from south to north along the

115 length of the Iquique segment (Fig. 1) agrees with the stress field predicted by the

116 forward models (Figs. 2, DR2). The cracks mapped near the city of Ilo, Peru lie near the

117 center of the estimated rupture zone of the 1868 earthquake and strike nearly

118 perpendicular to the $\sigma_{1}$ orientation predicted by the 1868 model, indicating that these

119 cracks are minimally affected by the static stress caused by earthquakes on this segment,

120 on which the great 1604 earthquake also occurred (Comte and Pardo, 1991). The mapped

121 cracks are suggested to have formed either during or shortly after the 2001 Arequipa

122 earthquake (Keefer and Moseley, 2004). En echelon map patterns of these cracks suggest

123 accommodation of WSW-directed left-lateral shear in addition to opening, consistent

124 with the kinematics reported for nearby faults (Audin et al., 2008). This indicates that the

125 cracks near Ilo are mixed-mode (1 and 2) and thus we expect that $\sigma_{1}$ for the stress field

126 that created them should be oblique to the crack strike as predicted by our model of the

1272001 event (Fig. DR4).

128 INVERTING CRACK DATA FOR PALEOSEISMIC SLIP

129 Studies of historical seismicity have relied on qualitative written records of

130 sustained damage (Comte and Pardo, 1991) to estimate event magnitude and location. 
Publisher: GSA

Journal: GEOL: Geology

Article ID: G25170

131 Given the agreement between predicted stress fields and observed crack strikes, we

132 propose that cracks can provide quantitative constraints on the slip distribution of paleo-

133 earthquakes. Because the inferred rupture limit of the 1877 earthquake encompasses 16

134 of the 17 cracked regions, we use the cracks to invert for plausible slip distributions

135 related to that event, or a sum of events occurring on the segment. In doing so, we make

136 the assumption that cracks used to constrain the slip pattern open exclusively due to

137 coseismic stress earthquakes on this segment, plus a contribution from regional stress

138 (see text in data repository).

139 The mean residual magnitude between the observed crack strikes and those

140 predicted by our preferred inversion is $8.2^{\circ}$ (Fig. 3). While the solution for coseismic slip

141 is non-unique (see text in data repository), several robust features are notable. The

142 greatest resolved slip is concentrated $\sim 35 \mathrm{~km}$ deep offshore Iquique $\left(20.25^{\circ} \mathrm{S}\right)$, consistent

143 with the depth of maximum slip during the 1995 earthquake and $\sim 1^{\circ}$ north of the

144 epicenter of the 1877 earthquake inferred from historical data (Comte and Pardo, 1991).

145 Smaller loci of moment release are located around $22.5^{\circ} \mathrm{S}$ and $23.5^{\circ} \mathrm{S}$. The distance

146 between slip patches suggests that they may represent separate earthquakes or widely

147 spaced asperities that rupture during a single event. Because of the lack of temporal

148 information contained in the data set, the crack-based strain field cannot distinguish a

149 single earthquake with a heterogeneous slip distribution from several smaller events.

150 Based on aftershocks mapped by the United States Geological Survey, the November

$1512007 M_{w} 7.7$ Tocopilla earthquake ruptured the margin between $\sim 22^{\circ}$ and $23^{\circ} \mathrm{S}$ (Fig. 3),

152 indicating that it broke a portion of the plate boundary on which little Iquique event slip 
Publisher: GSA

Journal: GEOL: Geology

Article ID: G25170

153 is predicted by the inversion. This suggests that much of the segment ruptures during

154 truly great earthquakes such as that of 1877 but the portions remaining unbroken slip in

155 smaller events.

\section{DISCUSSION}

157 Recent studies (Llenos and McGuire, 2007; Song and Simons, 2003; Wells et al.,

158 2003) have found a correlation between negative forearc trench-parallel gravity

159 anomalies (TPGA) and zones of large-magnitude slip during strong subduction zone

160 earthquakes. We construct a TPGA (Sandwell and Smith, 1997; Song and Simons, 2003)

161 field for the Iquique segment to compare with the slip distribution resolved from our

162 inversion of the crack-based strain data (Fig. 3). The region in which resolved slip is

163 greatest coincides with an area of strongly negative TPGA. The lack of resolved slip at

164 shallow depths south of $21^{\circ} \mathrm{S}$ and occurrence of the smaller Tocopilla earthquake near

$16522^{\circ} \mathrm{S}$ are consistent with the prevalence of positive TPGA, which predicts slip of lower

166 magnitude during the characteristic Iquique event. The forearc gravity field is not a

167 transient property, thus both the gravity field and our inversion of geological data place

168 constraints on long-term patterns of great earthquake slip.

169 In addition to the static stresses, dynamic stresses associated with the passage of

170 seismic waves can also cause cracking of the surface (Dalguer et al., 2003). We calculate

171 the temporal evolution of stress induced at the surface by the 1995 and 2001 earthquakes

172 and find that stress axes calculated from static dislocation models are reasonably similar

173 in orientation to the dynamic principal stresses (Fig. DR7). This indicates that our

174 regional-scale mapping of cracks places constraints on the extent and distribution of slip 
Publisher: GSA

Journal: GEOL: Geology

Article ID: G25170

175 associated with plate boundary earthquakes, regardless of whether static or dynamic

176 stress is the primary driver of crack evolution. The method used to calculate dynamic

177 stress (Cotton and Coutant, 1997) does not take into account changes in material

178 properties such as the presence of existing faults and lithologic heterogeneity that may

179 localize deformation. We suggest that dynamic stressing is responsible for the formation

180 of the cracks near Antofagasta, which formed in poorly consolidated sediments parallel to

181 a nearby NE-striking fault scarp during the 1995 event (González and Carrizo, 2003) and

182 may have been impacted by the soil characteristics and fault structure.

183 We suggest that great earthquakes along the northern Chile and southern Peru

184 margin repeatedly rupture areas several hundred $\mathrm{km}$ in length in quasi-characteristic

185 earthquakes. If the location of segment boundaries varied substantially on hundred k.y.

186 timescales, we would expect cracks to show a range of strikes rather than one or two

187 preferred orientations, or a greater frequency of lateral offset. Historic records show that

188 not all segments completely re-rupture in single earthquakes but may sometimes break in

189 several smaller events (Kanamori and McNally, 1982). However, our models of

190 earthquake slip and crack formation indicate that on a regional scale, the stress field is

191 more sensitive to the extent of slip than details of its distribution (Fig. DR6). This

192 suggests that earthquakes on a given segment of the plate boundary may vary in their slip

193 distribution, but the accumulated strain exhibited by surface cracks implies that the

194 dimensions and boundaries of characteristic earthquake rupture remain relatively

195 constant. 
Publisher: GSA

Journal: GEOL: Geology

Article ID: G25170

The existence of long-lived earthquake segments has several implications.

197 Knowledge of segment dimensions and boundary locations is important for determining

198 earthquake recurrence intervals and thus assess seismic hazard. Numerous explanations

199 for the segmented nature of subduction zone earthquakes have been proposed, including

200 topographic features on the slab, interaction with upper plate faults (Audin et al., 2008),

201 and changes in upper plate structure, and our suggestion that segments are long-lived and

202 can be mapped by surface features will provide important constraints on these

203 hypotheses. Finally, surface cracks have been observed to form coseismically in

204 numerous tectonic settings, including along strike-slip faults on the Tibetan Plateau (Bhat

205 et al., 2007) and in the Middle East (Fielding et al., 2005), and our work motivates large-

206 scale mapping of these features using high-resolution global imagery, such as that

207 available in Google Earth, to determine whether long-lived seismic segmentation exists in

208 these and other areas.

\section{ACKNOWLEDGMENTS}

210 This research is supported by NSF grants EAR-0337496 (to RWA) and EAR-

2110738507 (to RWA and MEP) and a NASA graduate research fellowship (NNG-04-

212 GQ-94-H, to JPL). Several figures were plotted using GMT (Wessel and Smith,

213 1991). We thank G. Hilley and D. Keefer for careful reviews, and B. Meade and F.

$214 \quad$ Maerten for helpful discussion.

\section{REFERENCES CITED}

216 Audin, L., Lacan, P., Tavera, H., and Bondoux, F., 2008, Upper plate deformation and

217 seismic barrier in front of Nazca subduction zone: The Chololo fault system and 
Publisher: GSA

Journal: GEOL: Geology

Article ID: G25170

active tectonics along the Coastal Cordillera, southern Peru: Tectonophysics, In press, doi: 10.1016/j.tecto.2007.11.070.

220 Bhat, H., Dmowska, R., King, G.C.P., Klinger, Y., and Rice, J.R., 2007, Off-fault

221 damage patterns due to supershear ruptures with application to the $2001 M_{w} 8.1$

222 Kokoxili (Kunlun) Tibet earthquake: Journal of Geophysical Research, v. 112,

223 B06301, doi: 10.1029/2006JB004425.

224 Comte, D., and Pardo, M., 1991, Reappraisal of great historical earthquakes in the

225 northern Chile and southern Peru seismic gaps: Natural Hazards, v. 4, p. 23-44, doi:

$226 \quad 10.1007 / \mathrm{BF} 00126557$.

227 Cotton, F., and Coutant, O., 1997, Dynamic stress variations due to shear faults in a

228 plane-layered medium: Geophysical Journal International, v. 128, p. 676-688, doi: 10.1111/j.1365-246X.1997.tb05328.x.

230 Dalguer, L.A., Irikura, K., and Riera, J.D., 2003, Simulation of tensile crack generation

231 by three-dimensional dynamic shear rupture propagation during an earthquake:

232 Journal of Geophysical Research, v. 108, 2144, doi: 10.1029/2001JB001738.

233 Dunai, T.J., González L., G.A., and Juez-Larré, J., 2005, Oligocene-Miocene age of

234 aridity in the Atacama Desert revealed by exposure dating of erosion-sensitive

235 landforms: Geology, v. 33, p. 321-324, doi: 10.1130/G21184.1.

236 Ewing, S., Sutter, B., Owen, J., Nishiizumi, K., Sharp, W., Cliff, S.S., Perry, K., Dietrich,

237 W., McKay, C.P., and Amundson, R., 2006, A threshold in soil formation at Earth's

238 arid-hyperarid transition: Geochimica et Cosmochimica Acta, v. 70, p. 5293-5322,

239 doi: 10.1016/j.gca.2006.08.020. 
Publisher: GSA

Journal: GEOL: Geology

Article ID: G25170

240 Fielding, E.J., Talebian, M., Rosen, P.A., Nazari, H., Jackson, J.A., Ghorashi, M., and

241 Walker, R., 2005, Surface rupture and building damage of the 2003 Bam, Iran

242 earthquake mapped by satellite synthetic aperture radar interferometric correlation:

243 Journal of Geophysical Research, v. 110, B03302, doi: 10.1029/2004JB003299.

244 González, G., and Carrizo, D., 2003, Segmentación, cinemática y chronología relativa de

245 la deformación tardía de la Falla Salar del Carmen, Sistema de Fallas Atacama,

246 (2340'S), norte de Chile: Revista Geológica de Chile, v. 30, p. 223-244.

247 [IQ1: There is some discrepancy between "Gonzalez L." or just "Gonzalez."

248 Please choose one and make it consistent for all references to this author.

249 Q1]|González, G., Dunai, T., Carrizo, D., and Allmendinger, R., 2006, Young

250 displacements on the Atacama Fault System, northern Chile from field observations

251 and cosmogenic ${ }^{21} \mathrm{Ne}$ concentrations: Tectonics, v. 25, TC3006, doi:

$252 \quad 10.1029 / 2005 T C 001846$

253 González, G., Gerbault, M., Martinod, J., Cembrano, J., Carrizo, D., Allmendinger, R.,

254 and Espina, J., 2008, Crack formation on top of propagating reverse faults of the

255 Chuculay Fault System, northern Chile: Insights from field data and numerical

256 modelling: Journal of Structural Geology, v. 30, p. 791-808, doi:

$257 \quad$ 10.1016/j.jsg.2008.02.008.

258 Hartley, A.J., and Chong, G., 2002, Late Pliocene age for the Atacama

259 Desert:Implications for the desertification of western South America: Geology, v. 30,

260 p. 43-46, doi: 10.1130/0091-7613(2002)030<0043:LPAFTA>2.0.CO;2. 
Publisher: GSA

Journal: GEOL: Geology

Article ID: G25170

261 Kanamori, H., and McNally, K., 1982, Variable rupture mode of the subduction zone

262 along the Ecuador-Columbia coast: Bulletin of the Seismological Society of

263 America, v. 72, p. 1241-1253.

264 Keefer, D.K., and Moseley, M.E., 2004, Southern Peru desert shattered by the great 2001

265 earthquake: Implications for paleoseismic and paleo-El Niño-Southern Oscillation

266 records: Proceedings of the National Academy of Sciences of the United States of

267 America, v. 101, p. 10878-10883, doi: 10.1073/pnas.0404320101.

268 Llenos, A.L., and McGuire, J.J., 2007, Influence of fore-arc structure on the extent of

269 great subduction zone earthquakes: Journal of Geophysical Research. Solid Earth,

270 v. 112, B09301, doi: 10.1029/2007JB004944.

271 Loveless, J.P., 2008, Extensional tectonics in a convergent margin setting: Deformation

272 of the northern Chilean forearc [PhD. thesis]: Ithaca, NY, Cornell University.

273 Loveless, J.P., Hoke, G.D., Allmendinger, R.W., González, G., Isacks, B.L., and Carrizo,

274 D.A., 2005, Pervasive cracking of the northern Chilean Coastal Cordillera: New

275 evidence for forearc extension: Geology, v. 33, p. 973-976, doi: 10.1130/G22004.1.

276 Maerten, F., Resor, P., Pollard, D.D., and Maerten, L., 2005, Inverting for slip on three-

277 dimensional fault surfaces using angular dislocations: Bulletin of the Seismological

278 Society of America, v. 95, p. 1654-1665, doi: 10.1785/0120030181.

279 Marquardt, C., Naranjo, J.A., and Lavenu, A., 2006, Efectos geológicos del sismo del 13

280 de junio 2005, Región de Tarapacá, XI Congreso Geológico Chileno, Volume 2:

281 Antofagasta, Chile, p. 435-438. 
Publisher: GSA

Journal: GEOL: Geology

Article ID: G25170

282 Pollard, D.D., and Segall, P., 1987, Theoretical displacements and stresses near fractures

283 in rock: With applications to faults, joints, veins, dikes, and solution surface, in

284 Atkinson, B.K., ed., Fracture Mechanics of Rock: London, Academic Press, p. 277-

285349.

286 Pritchard, M.E., Ji, C., and Simons, M., 2006, Distribution of slip from $11 M_{w}>6$

287 earthquakes in the northern Chile subduction zone: Journal of Geophysical Research,

$288 \quad$ v. 111, B10302, doi: 10.1029/2005JB004013.

289 Pritchard, M.E., Norabuena, E.O., Ji, C., Boroschek, R., Comte, D., Simons, M., Dixon,

290 T., and Rosen, P.A., 2007, Geodetic, teleseismic, and strong motion constraints on

291 slip from recent southern Peru subduction zone earthquakes: Journal of Geophysical

292 Research, v. 112, B03307, doi: 10.1029/2006JB004294.

293 Rech, J.A., Currie, B.S., Michalski, G., and Cowan, A.M., 2006, Neogene climate change

294 and uplift in the Atacama Desert, Chile: Geology, v. 34, p. 761-764, doi:

$295 \quad 10.1130 / \mathrm{G} 22444.1$.

296 Rech, J.A., Quade, J., and Hart, W.S., 2003, Isotopic evidence for the source of Ca and S

297 in soil gypsum, anhydrite and calcite in the Atacama Desert, Chile: Geochimica et

298 Cosmochimica Acta, v. 67, p. 575-586, doi: 10.1016/S0016-7037(02)01175-4.

299 Sandwell, D.T., and Smith, W.H.F., 1997, Marine gravity anomaly from Geosat and ERS

3001 satellite altimetry: Journal of Geophysical Research, v. 102, p. 10,039-10,054, doi:

$301 \quad 10.1029 / 96 J B 03223$. 
Publisher: GSA

Journal: GEOL: Geology

Article ID: G25170

302 Schwartz, D.P., and Coppersmith, K.J., 1984, Fault behavior and characteristic

303 earthquakes: Examples from the Wasatch and San Andreas fault zones: Journal of

304 Geophysical Research, v. 89, p. 5681-5698, doi: 10.1029/JB089iB07p05681.

305 Sieh, K., 1996, The repetition of large-earthquake ruptures: Proceedings of the National

306 Academy of Sciences of the United States of America, v. 93, p. 3764-3771, doi:

$307 \quad 10.1073 /$ pnas.93.9.3764.

308 Song, T.-R.A., and Simons, M., 2003, Large trench-parallel gravity variations predict

309 seismogenic behavior in subduction zones: Science, v. 301, p. 630-633, doi:

$310 \quad 10.1126 /$ science.1085557.

311 Wells, R.E., Blakely, R.J., Sugiyama, Y., Scholl, D.W., and Dinterman, P.A., 2003,

312 Basin-centered asperities in great subduction zone earthquakes: A link between slip,

313 subsidence, and subduction erosion?: Journal of Geophysical Research, v. 108, 2507,

314 doi: 10.1029/2002JB002072.

315 FIGURE CAPTIONS

316 Figure 1. Map of the northern Chile and southern Peru forearc regions. Ovals indicate the

317 approximate rupture segments of the most recent earthquakes on four segments of the

318 plate boundary; large dots represent the inferred epicenters. Rose diagrams show the

319 length-weighted distribution of crack strikes, with the black vector denoting the mean

320 strike. Inverted triangles show the position of the population; filled symbols denote

321 bimodal distribution in strike (see data repository). The dark gray region onshore shows

322 the area lying between $300 \mathrm{~m}$ and $1200 \mathrm{~m}$ elevation, delineating the bounds within which

323 gypsum precipitates from the dense coastal fog (Rech et al., 2003). The inset IKONOS 
Publisher: GSA

Journal: GEOL: Geology

Article ID: G25170

324 satellite image in the upper right corner shows an example of surface cracking. Cracks

325 are concentrated in gypsum-indurated sediment and are identified as parallel, N-S striking

326 dark lines in the light colored sediment. The darker regions are unconsolidated sediments

327 in which cracks are not well preserved.

328 Figure 2. Schematic relationship between subduction zone earthquake rupture area

329 (offshore ellipse with bold arrows denoting the coseismic slip vector) and principal stress

330 exerted at the surface. Gray arrows show $\sigma_{3}$ axes, which are approximately parallel to the

331 slip vector near the center of the rupture segment, opening cracks (narrow white ovals)

332 that strike in a perpendicular direction, parallel to the $\sigma_{1}$ direction (black axes). Near the

333 rupture terminations, cracks strike oblique to the earthquake slip vector.

334 Figure 3. Preferred inverse model of the 1877 Iquique earthquake, shown as $1 \mathrm{~m}$ interval

335 contour lines of coseismic slip. The slip distribution was calculated by inverting (Maerten

336 et al., 2005) the strain field represented by the populations of surface cracks for slip on

337 the subduction interface. The mean crack strike at each mapped locality is shown by a red

338 bar and the calculated $\sigma_{1}$ orientation at the same location is indicated by a blue bar; the

339 mean residual angle between the observed and predicted crack strike is $8.2^{\circ}$. The contours

340 are overlain on the trench-parallel gravity anomaly (TPGA) constructed for the Iquique

341 segment. The region of greatest resolved slip for the Iquique event coincides with

342 strongly negative TPGA, consistent with recent studies (Llenos and McGuire, 2007; Song

343 and Simons, 2003; Wells et al., 2003). The approximate rupture area of the November

$3442002 M_{w} 7.7$ Tocopilla earthquake is shown as the dashed rectangle, based on

345 information from the United States Geological Survey. 
Publisher: GSA

Journal: GEOL: Geology

Article ID: G25170

$346{ }^{1}$ Data repository contains supplementary text, 7 figures, 3 tables.

$347{ }^{2}$ GSA Data Repository item 2008xxx, xxxxxxxx, is available online at

348 www.geosociety.org/pubs/ft2008.htm, or on request from editing@geosociety.org or

349 Documents Secretary, GSA, P.O. Box 9140, Boulder, CO 80301, USA. 


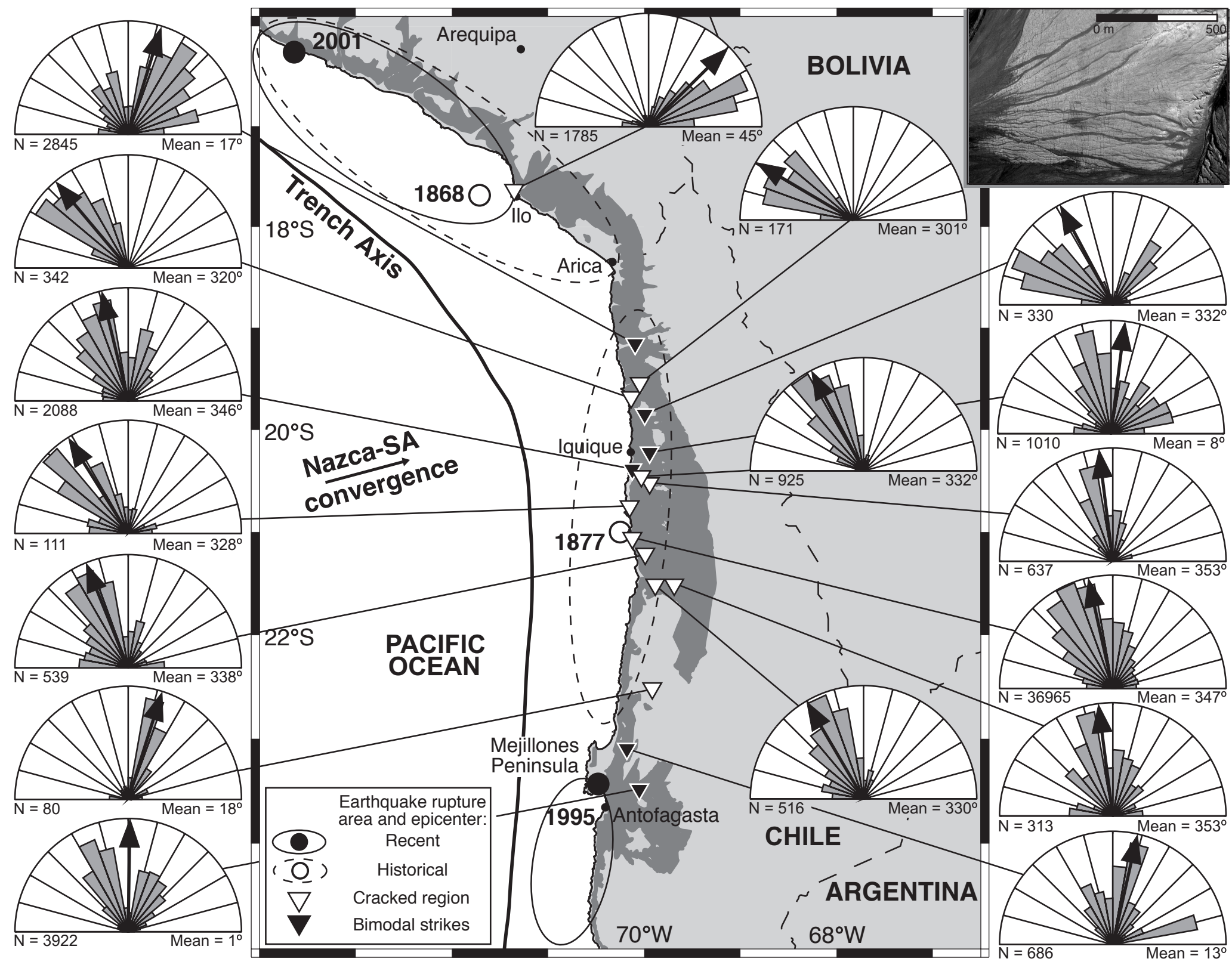




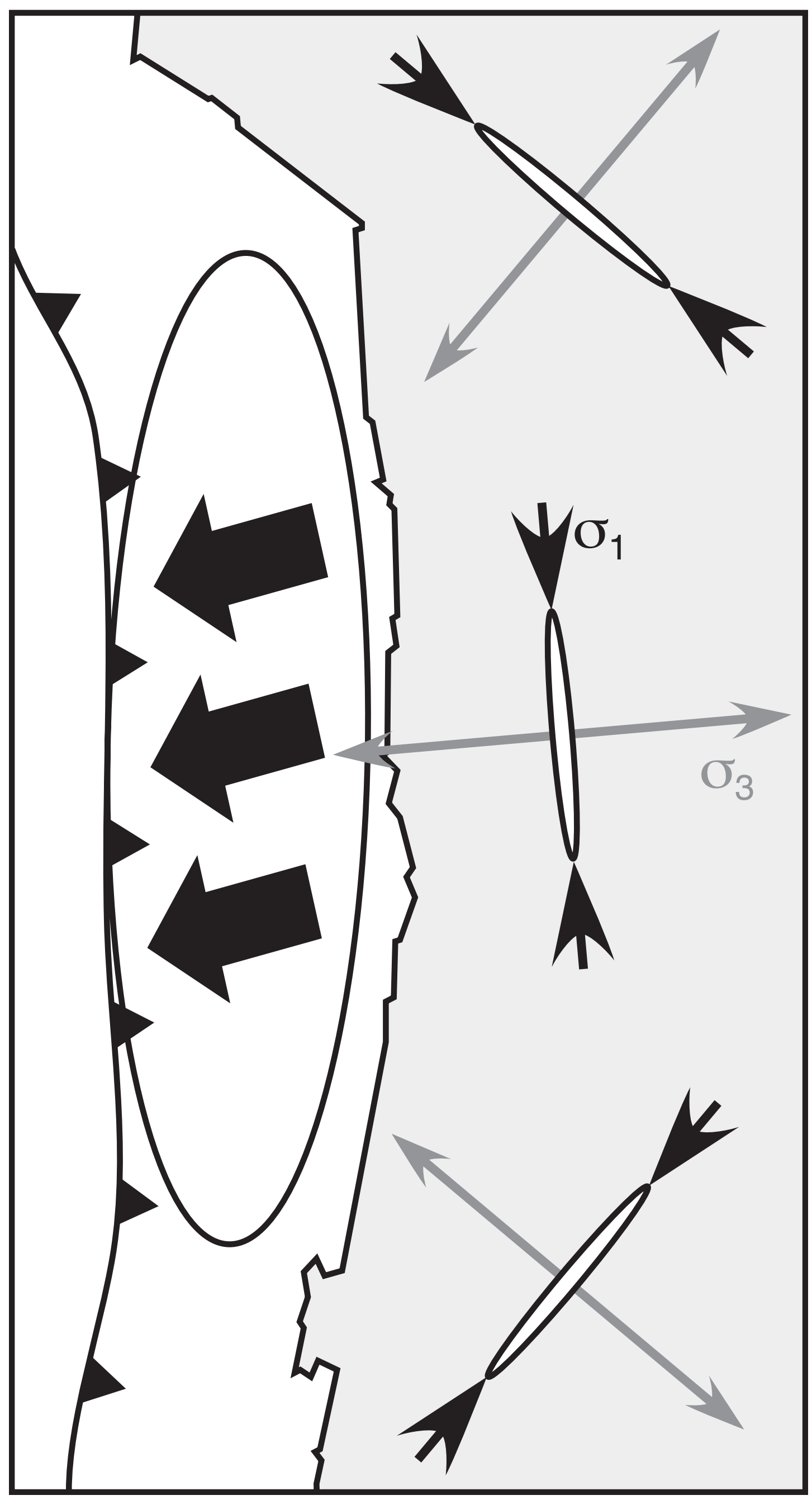




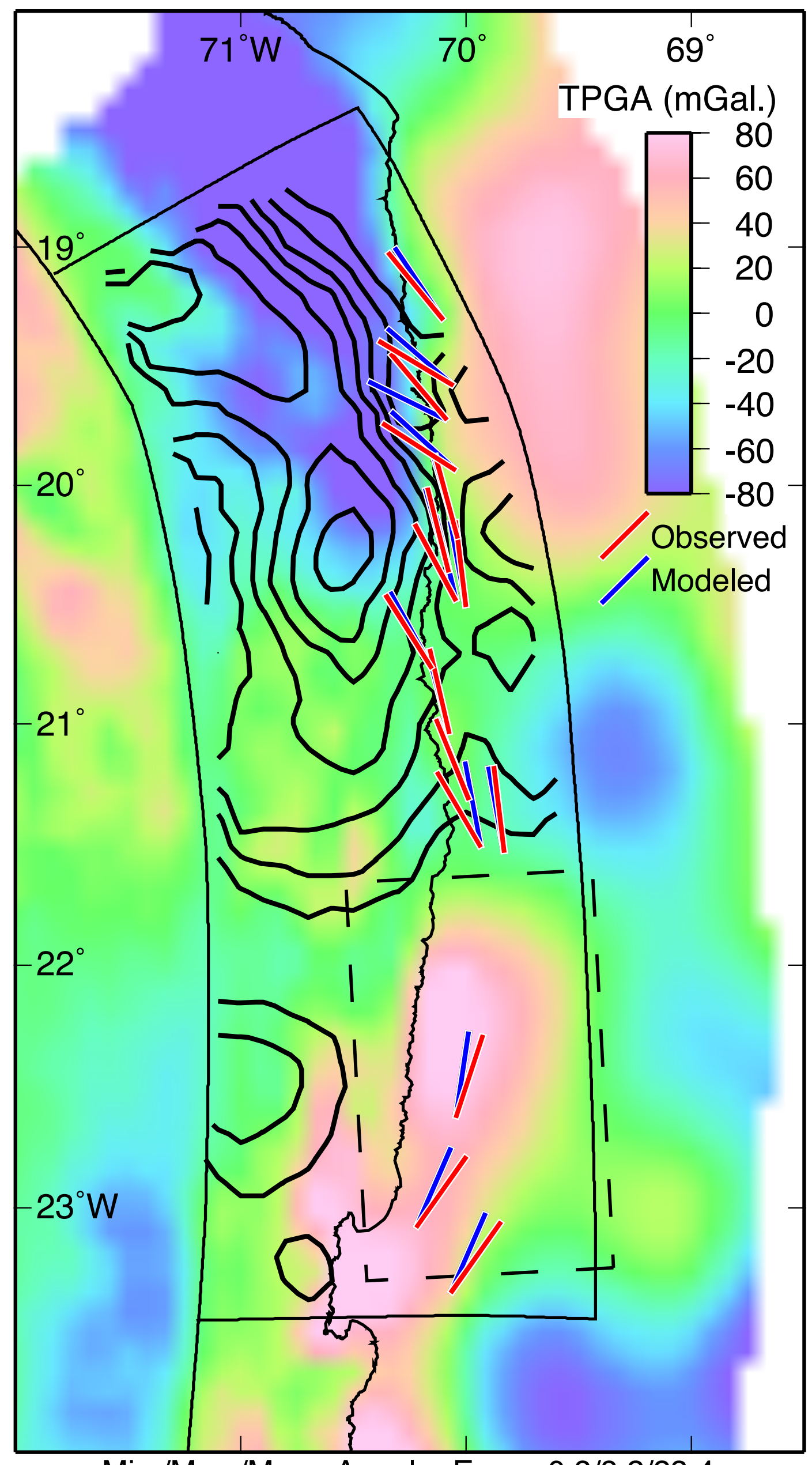

Min./Max./Mean Angular Error: 0.8/8.2/23.4 